\title{
Physical and Mechanical Characteristics of Feather Fiber based Filled Circular Tube
}

\author{
Sandesh Kiran. $\mathrm{S}^{1}$ \\ ${ }^{1}$ Research Scholar, \\ Department of Mechanical Engineering, \\ University Visvesvaraya College of Engineering, \\ Bangalore, India
}

\author{
B. M. Rajaprakash ${ }^{1}$ \\ ${ }^{2}$ Professor, \\ Department of Mechanical Engineering, \\ University Visvesvaraya College of Engineering, \\ Bangalore, India
}

\begin{abstract}
Application of feather fibers in engineering applications is on growing trend and feather fibers are used in composite panels and thermal insulations. The intent of this paper aimed to study physical and mechanical properties of feather fiber based filled tube which is also known as FETUBE. Physical and mechanical properties are crucial to evaluate the industrial application of FETUBE. Experimental tests were conducted on FETUBE to evaluate tensile and compressive strength. Apart from tensile and compressive strength tests, various other important test such as bending strength, shear strength, torsion strength, and impact strength were conducted on FETUBE. The toughness of tube and modulus of elasticity were evaluated as a function of percentage of moisture content. Test results were reviewed and conclusions were drawn based on the exponential data. Experimental tests were conducted considering the average diameter of the FETUBE.
\end{abstract}

Keywords: Natural fibers, Feather Fiber based filled tube, FETUBE, physical and mechanical properties of feather fibers.

\section{INTRODUCTION}

Natural fibers have inherent superiority over conventional synthetic fiber materials, such as weight to strength ratio, cost advantages, raw material availability, carbon foot print and degradability. Poultry feather fibers (FFs) are gaining popularity in industrial applications and in the field of composite applications. Fibers play vital role in matrix based composites and synthetic fibers are being used extensively in the composite panel manufacturing. Environmental issues and dependency on petroleum based products made the composite industry to look for better options to use natural fibers and ecofriendly polymers from renewable resources.

Natural fibers can be broadly classified as cellulose based and protein based fibers. Animal based fibers are protein based fibers. Over 3.8 million metric tons of poultry meat was produced across India in 2019[1]. It was estimated that $6 \%$ of a bird's body weight is feathers [3], the amount of feathers coming out of Indian poultry facility is around is about 0.32 million metric tons. Usually poultry feathers are treated as waste, and disposed in open ground or burned. Disposal of the poultry waste is very expensive and produces bad odder and ill effects on surrounding environment [4]. The use of poultry feather fiber as reinforcement in composites is an innovative solution for poultry feather waste disposition and also provides additional revenue for the poultry industry. Bird feathers are considered as the most conglomerate integumentary appendages in vertebrates [5]. Feather fibers are made of keratin proteins ([90 wt \%) [6] and the amino acid contents were studied by Graham [7], Schmidt [8], and Franer et al. [9].

Poultry feathers have two important parts namely feather fiber and quill and they are equal in weight percentage contribution. Poultry feathers inclusive of quill and feather fibers are made of protein known as hydrophobic keratin, which has strength comparable to nylon and cross-sectional diameter smaller than wood fiber [10]. Feather fiber has high aspect ratio than the quill and very good durability. Feathers extracted and collected from poultry facility cannot be made into new materials and needs cleaning process. The central part of feather known as core is also called as feather quill, is a stiff part and must be separated from the barbs. Barbs can be used as reinforcement material for composites and barbs in powder format can be used as fillers in matrix materials. Feather barbs are comparatively shorter in length and cannot be spun into thread and cannot be woven into cloth due to surface property of the feather fibers, but they can be added with man-made synthetic materials to form mat or slab where fibers are randomly oriented. The length of the barbs purely depends on the position along the rachis. The barbs on the base of the rachis are longer when compared to the fibers at the tip. Feather fiber property depends upon the percentage of keratin, which varies with ecological conditions of poultry facility [11-15]. 


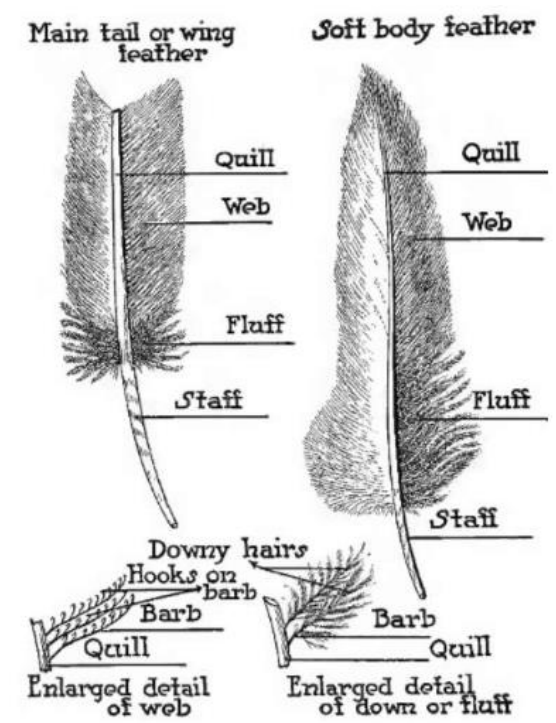

Figure.1 Details of Poultry feathers [18]

The average length of poultry feathers are roughly around $135 \mathrm{~mm}$. The density of poultry feathers was found to be around 0.8 $\mathrm{g} / \mathrm{cm} 3$ and know to be lighter material [16]. Feather fiber diameters were found to be in the range of 5 $\mathrm{mm}$ and lengths of 3-13 mm. These values correspond to aspect ratios of 400-2200. Mature and well grown 5lb or $2.25 \mathrm{~kg}$ broiler chicken's feathers weigh about 74 grams or 2.6 ounces, or 3.3 percent of its body weight. Since that chicken has some 9,000 feathers, each one weighs about 0.0082 grams [17]. Some of the important tests and results on poultry feathers are tabulated in Table.1, Table.2 and Table. 3

Table.1 Tensile Test details of Feather Quill

\begin{tabular}{|c|l|l|l|l|l|l|}
\hline Sample & $\begin{array}{l}\text { Breaking } \\
\text { load N }\end{array}$ & $\begin{array}{l}\text { Deformation } \\
\text { at Break mm }\end{array}$ & $\begin{array}{l}\text { Tensile } \\
\text { Deformation } \\
\text { at break mm }\end{array}$ & Average & $\begin{array}{l}\text { Average } \\
\text { stress } \\
\text { N/mm2 }\end{array}$ & $\begin{array}{l}\text { Younges } \\
\text { sodules E } \\
\text { Mpa }\end{array}$ \\
\hline 1 & 34.07 & 0.37 & 0.3759 & 0.035 & 6.00 & 173 \\
\hline 2 & 36.81 & 0.897 & 0.896 & 0.045 & 6.55 & 147 \\
\hline 3 & 35.02 & 0.394 & 0.395 & 0.032 & 6.13 & 189 \\
\hline 4 & 36.11 & 0.473 & 0.47 & 0.032 & 6.13 & 189 \\
\hline 5 & 36.17 & 0.341 & 0.34 & 0.016 & 5.87 & 364 \\
\hline Max. & $\mathbf{3 6 . 8 1}$ & $\mathbf{0 . 8 9 7}$ & $\mathbf{0 . 8 9 6}$ & 0.045 & 6.55 & 364 \\
\hline Min. & $\mathbf{3 5 . 0 1}$ & $\mathbf{0 . 3 4 1}$ & $\mathbf{0 . 3 4}$ & 0.016 & 5.87 & 173 \\
\hline
\end{tabular}

Table.2 Fluid Resistance test of the Quill and Barbs

\begin{tabular}{|c|l|l|l|}
\hline SL.No & \multicolumn{1}{|c|}{ Test medium } & Quill after 24hrs drying & \multicolumn{1}{|c|}{ Barbs after 24hts drying } \\
\hline 1 & Cold Water & $1.1 \%$ Weight loss & $1.52 \%$ weight loss \\
\hline 2 & Hot Water & $1.5 \%$ Weight loss & $2.56 \%$ weight loss \\
\hline 3 & $\begin{array}{l}\text { With } 2 \% \mathrm{Na}_{2} \mathrm{CO}_{3} \\
(\text { Washing Soda })\end{array}$ & $1.64 \%$ Weight loss & $18.877 \%$ Weight los \\
\hline 4 & $\begin{array}{l}\text { With } 1 \% \mathrm{Hcl} \\
(\text { Hydrochloric acid })\end{array}$ & $5.65 \%$ weight loss & $4.494 \%$ Weight los \\
\hline 5 & $\begin{array}{l}\text { With } 5 \% \mathrm{NaOH} \\
\text { (Sodium Hydroxide) }\end{array}$ & Completely dissolved & $9.14 \%$ Weight loss \\
\hline
\end{tabular}

Table.3 Flammability Response of Feathers

\begin{tabular}{|c|l|l|l|l|l|l|}
\hline \multirow{2}{*}{ Sl.No } & \multirow{2}{*}{ Description } & \multicolumn{3}{|c|}{ Burning Behaviour } & \multirow{2}{*}{ Residue } \\
\cline { 3 - 6 } & When approached Flame & When in the Flame & Removed from the Flame & Odour \\
\hline 1 & Quill & Fuses & Fuses and Burns & $\begin{array}{c}\text { Supports combustion for a } \\
\text { long time }\end{array}$ & $\begin{array}{c}\text { Easily crushable. Black } \\
\text { Soft ash }\end{array}$ & Burning rubber \\
\hline 2 & Barbs & Fuses & Fuses and burns & $\begin{array}{c}\text { Supports combustion for a } \\
\text { short time }\end{array}$ & Completely Fuses & Burning Hair \\
\hline
\end{tabular}




\section{POULTRY FEATHER FIBER BASED FILLED TUBE- FETUBE}

FETUBE is a newly developed proprietary material made from bundles of poultry feathers in a particular pattern. Clean and processed loose bundled feathers with or without quill reinforcement, wrapped in thin layer cotton based lenin was moulded in split pipe mold to form a filled tube. Dilute SR998 rubber based resin was used during the bundling process of feather fibers. FETUBE is vacuum cured and temperature cured as per the form fit functional requirements. Diameter of the tube ranges from $4 \mathrm{~mm}$ to $12 \mathrm{~mm}$ and tubes of diameter less than $6 \mathrm{~mm}$ are without quill reinforcement and tubes with diameter greater than $6 \mathrm{~mm}$, comes with quill reinforcement of diameter $3 \mathrm{~mm}$ to $4 \mathrm{~mm}$. The wrapping of thin layer of cotton based lenin acts like braiding and holds loose feather fibers intact. The exterior surface of the tube is provided with thin coating of SR998 to prevent moisture entrapment and activated surface for future fabrication. Visually, FETUBE resembles as dried maize stalk with good bending property.

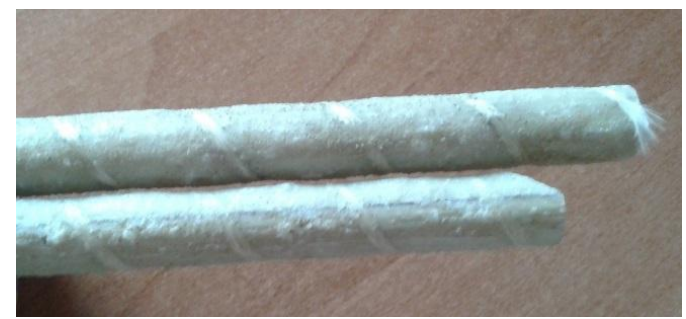

Figure-2 Feather Fiber based filled tube - FETUBE

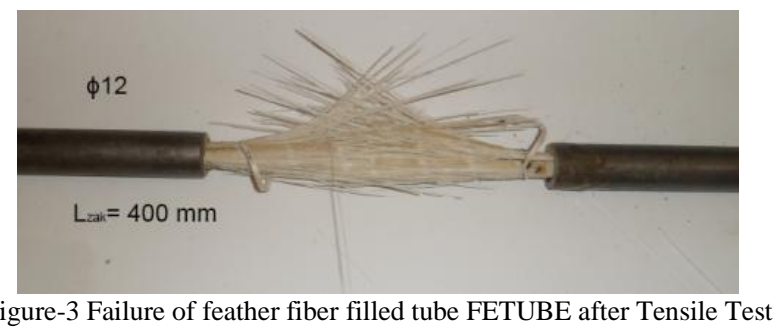

Based on preliminary testing, the axial tensile strength of diameter $\varnothing 12 \mathrm{~mm}$ FETUBE was $53.96 \mathrm{MPa}$. The average secant modulus of elasticity is $28.06 \mathrm{GPa}$ and the average boundary deformation is equal to $0.98 \%$. The destruction of the rods took place by cracking of the subsequent fibers. The detachment of the braiding from the bar core was noticeable. The destruction was accompanied by a decrease of strength. The intent of this paper is to study the behavior of FETUBE in detail so that FETUBE can be used in generic and industrial applications

\section{PHYSICAL CHARACTERISTICS OF FEATHER FIBER BASED TUBE - FETUBE}

FETUBE samples are available in running length and maximum length of the FETUBE is $1.25 \mathrm{~m}$. FETUBES are available in standard cross sectional diameter starting from $6 \mathrm{~mm}$ to $12 \mathrm{~mm}$. The test samples of FETUBEs were prepared as pert test requirements. The important physical parameter for specific tests are tabulated in Table.4. Test samples were cut from the standard length tubes and were stored in oven maintained at $27^{\circ} \mathrm{C}$ with humidity $50 \%$. 10 specimens were prepared for each specific type of test.

Table.4 FETUBE - Test Specimen Geometry information

\begin{tabular}{|c|c|c|}
\hline \multirow{2}{*}{ Physical Property } & \multicolumn{2}{|c|}{ FETUBE } \\
\cline { 2 - 3 } & Range & Average \\
\hline \multirow{2}{*}{ Tube length, cm } & $140-150$ & 146.09 \\
\cline { 2 - 3 } & $298-305$ & 302 \\
\cline { 2 - 3 } & $430-440$ & 437 \\
\hline Tube diameter, $(6) \mathrm{mm}$ & $5.2-6.1$ & 5.91 \\
\hline Tube diameter, $(8) \mathrm{mm}$ & $7.9-8.2$ & 8.01 \\
\hline Tube diameter, $(12) \mathrm{mm}$ & $11.4-12.2$ & 12.04 \\
\hline Mass of one $6 m m$ Dia Tube, $(\mathrm{g})$ & $6.8-7.3$ & 7 \\
\hline Mass of one $8 \mathrm{~mm}$ Dia Tube, $(\mathrm{g})$ & $7.9-8.6$ & 8.4 \\
\hline Mass of one $12 \mathrm{~mm}$ Dia Tube, $(\mathrm{g})$ & $11.92-12.3$ & 10.11 \\
\hline
\end{tabular}


The properties which influence the physical behavior of the feather fiber tube FETUBE are shear, compression and bending characteristics. Table. 5 tabulates the details of important tests for FETUBE.

Table.5 Important properties for FETUBE

\begin{tabular}{|c|c|c|c|}
\hline Test Type & Parameters & formula & Description \\
\hline Shear Test & Maximum shear strength & $\sigma_{\mathrm{s}}=\mathrm{F}_{\max } / \mathrm{A}$ & $\begin{array}{l}\sigma_{\mathrm{s}} \text { are the maximum shear strength in }(\mathrm{MPa}) \\
\mathrm{F}_{\max } \text { is the maximum shear force in }(\mathrm{N}) \\
\mathrm{A} \text { is the crosssectional area of stalk at the plane of shear in }\left(\mathrm{mm}^{2}\right)\end{array}$ \\
\hline Compression Test & $\begin{array}{l}\text { Modulus of elasticity } \\
\text { (compression) }\end{array}$ & $\sigma_{c}=[(F c / A) /(\Delta L / d)]$ & $\begin{array}{l}\sigma_{c} \text { is the modulus of elasticity in compression in }\left(\mathrm{N} / \mathrm{mm}^{2}\right) \\
\mathrm{Fc} \text { is the compressive force in }(\mathrm{N}) \\
\Delta \mathrm{L} \text { is the transverse deformation due to compressive force in }(\mathrm{mm}) \\
\mathrm{d} \text { is the diameter of the stalk at the point of compression in }(\mathrm{mm})\end{array}$ \\
\hline Bending Test & $\begin{array}{l}\text { Beam failure stress } \\
\text { Modulus of elasticity(bending ) } \\
\text { Bending energy }\end{array}$ & $\begin{aligned} \sigma b & =M y / I \\
M & =F_{b} \times L\end{aligned}$ & $\begin{array}{l}M \text { is the maximum bending moment at which thetube fails in (Nmm) } \\
y \text { is the distance of outermost fibre from the neutral axis in }(\mathrm{mm}) \\
\mathrm{I} \text { is the second moment of area of the stem cross-section in }\left(\mathrm{mm}^{4}\right) \\
F_{b} \text { is the maximum bending force at which the tube fails in }(\mathrm{N}) \\
\mathrm{L} \text { is the length of lever arm of the bending force in }(\mathrm{mm}) \text {. }\end{array}$ \\
\hline
\end{tabular}

\section{MATERIAL AND METHODS}

The test samples were stored in oven to eliminate the moisture entrapment. The oven was maintained at $30^{\circ} \mathrm{C}$ and at $50 \%$ humidity. Universal testing machine (UTM) maintained at standard laboratory condition was used to measure the mechanical properties (tensile strength and compressive strength at vertical plane) for FETUBE,. The machine as shown in Fig. (1). Test sample dimensions are tabulated in Table.6.

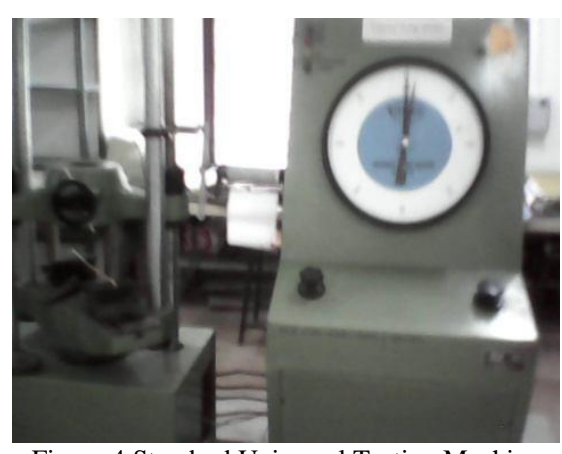

Figure.4 Standard Universal Testing Machine

Table.6. Geometrical Dimension of Test Samples

\begin{tabular}{|c|l|c|l|}
\hline S1.No & \multicolumn{1}{|c|}{ Test Type } & Sample Length & \multicolumn{1}{|c|}{ Sample Diameter } \\
\hline 1 & Shear strength. & $30 \mathrm{~mm}$ & 6,8 and $12 \mathrm{~mm}$ \\
\hline 2 & Compres sive strength. & $25 \mathrm{~mm}$ & 6,8 and $12 \mathrm{~mm}$ \\
\hline 3 & Tensile strength. & $300 \mathrm{~mm}$ & 6,8 and $12 \mathrm{~mm}$ \\
\hline 4 & Bending movement. & $430 \mathrm{~mm}$ & 6,8 and $12 \mathrm{~mm}$ \\
\hline 5 & Impact test & $80 \mathrm{~mm}$ & 6,8 and $12 \mathrm{~mm}$ \\
\hline 6 & Torsion test & $350 \mathrm{~mm}$ & 6,8 and $12 \mathrm{~mm}$ \\
\hline 7 & Moisture content (M.C) & $300 \mathrm{~mm}$ & 6,8 and $12 \mathrm{~mm}$ \\
\hline
\end{tabular}

\subsection{Shear strength Test on FETUBE}

The shear behavior of FETUBE was determined experimentally by shear strength test and the maximum shear stress $\sigma \mathrm{s}$ are expressed by the equation $\sigma \mathrm{s}=\mathrm{Fmax} / \mathrm{A}$. Shear strength test needs a separate pre-fabricated fixture which will be fixed rigidly to the base plate of UTM. FETUBE can be tested single and double shear strength test and is illustrated in Figure.5. The geometry of the test specimen is tabulated in Table.6. The conditioned FETUBE sample was held on the fixture with the help of U-clamps at both ends of the test specimens. During the down ward movement of the crosshead, the chisel cut the specimen by shear and passed through the slots provided in the fixture below the specimen. The force required for shearing the stalk was recorded. The maximum shear strength was calculated using equation $\sigma \mathrm{s}=\mathrm{Fmax} / \mathrm{A}$. The shear test was conducted for different type of FETUBE which are with and without quill reinforment. 


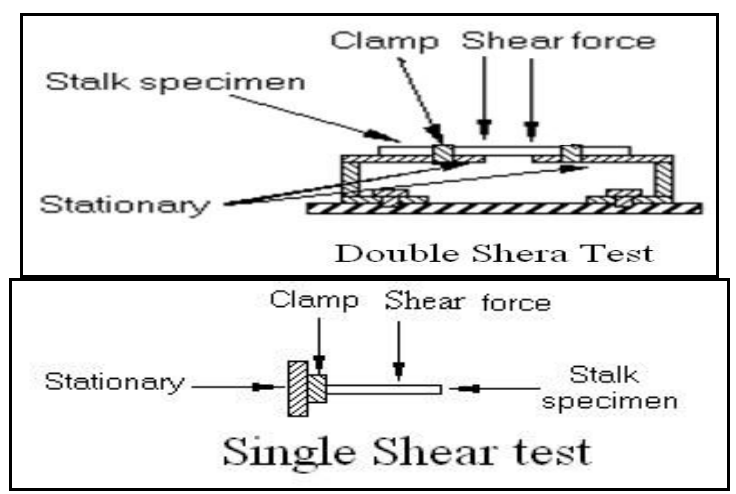

Figure. 5 Shearing testing methodology for FETUBE

Table.7 Double Shear Testing results of FETUBE

\begin{tabular}{|c|c|c|c|c|c|}
\hline \multirow{3}{*}{$\begin{array}{l}\text { Sample C/S } \\
\text { (Dia in mm) }\end{array}$} & Average & \multirow{3}{*}{ Area $\left(\mathrm{mm}^{2}\right)$} & Peak load & Peak load & $\begin{array}{c}\text { Shear } \\
\text { strength }\end{array}$ \\
\hline & Diameter & & $(\mathbf{K N})$ & $(\mathbf{N})$ & $\left(\mathrm{N} / \mathrm{mm}^{2}\right)$ \\
\hline & $(\mathbf{m m})$ & & & & \\
\hline \multirow{3}{*}{$\begin{array}{l}12 \mathrm{~mm} \text { Dia } \\
\text { FETUBE }\end{array}$} & 11.97 & 112.48 & 5.5 & 5500 & 48.90 \\
\hline & 12.03 & 113.61 & 5.2 & 5200 & 45.77 \\
\hline & 12.07 & 114.36 & 5.8 & 5800 & 50.72 \\
\hline \multirow{3}{*}{$\begin{array}{l}8 \mathrm{~mm} \text { Dia } \\
\text { FETUBE }\end{array}$} & 8.1 & 51.50 & 4.1 & 4100 & 79.61 \\
\hline & 8.03 & 50.62 & 3.96 & 3960 & 78.23 \\
\hline & 7.9 & 48.99 & 3.91 & 3910 & 79.81 \\
\hline \multirow{3}{*}{$\begin{array}{l}\text { 6mm Dia } \\
\text { FETUBE }\end{array}$} & 5.93 & 27.60 & 3.11 & 3110 & 112.66 \\
\hline & 5.99 & 28.17 & 3.07 & 3070 & 109.00 \\
\hline & 6.1 & 29.21 & 3.21 & 3210 & 109.89 \\
\hline
\end{tabular}

Table. 8 Single Shear Testing results of FETUBE

\begin{tabular}{|c|c|c|c|c|c|}
\hline \multirow{3}{*}{$\begin{array}{r}\text { Sample C/S } \\
\text { (Dia in } \mathbf{~ m m} \text { ) }\end{array}$} & \multirow{3}{*}{\begin{tabular}{|c|} 
Diameter \\
$(\mathbf{m m})$
\end{tabular}} & \multirow{3}{*}{ Area $\left(\mathbf{m m}^{2}\right)$} & \multirow{2}{*}{$\begin{array}{c}\text { Peak load } \\
(\mathrm{KN}) \\
\end{array}$} & \multirow{3}{*}{$\begin{array}{c}\text { Peak load } \\
(\mathbf{N}) \\
\end{array}$} & \multirow{3}{*}{$\begin{array}{c}\begin{array}{c}\text { Shear } \\
\text { strength }\end{array} \\
\left(\mathrm{N} / \mathrm{mm}^{2}\right) \\
\end{array}$} \\
\hline & & & & & \\
\hline & & & & & \\
\hline \multirow{3}{*}{$\begin{array}{l}12 \mathrm{~mm} \text { Dia } \\
\text { FETUBE }\end{array}$} & 11.9 & 111.16 & 5.7 & 5700 & 51.28 \\
\hline & 12.01 & 113.23 & 5.4 & 5400 & 47.69 \\
\hline & 12 & 113.04 & 6 & 6000 & 53.08 \\
\hline \multirow{3}{*}{$\begin{array}{l}\text { 8mm Dia } \\
\text { FETUBE }\end{array}$} & 8.02 & 50.49 & 4.7 & 4700 & 93.08 \\
\hline & 8.07 & 51.12 & 4.5 & 4500 & 88.02 \\
\hline & 7.95 & 49.61 & 4.11 & 4110 & 82.84 \\
\hline \multirow{3}{*}{$\begin{array}{l}\text { 6mm Dia } \\
\text { FETUBE }\end{array}$} & 5.97 & 27.98 & 3.71 & 3710 & 132.60 \\
\hline & 6.04 & 28.64 & 3.57 & 3570 & 124.66 \\
\hline & 6.01 & 28.35 & 3.31 & 3310 & 116.74 \\
\hline
\end{tabular}

\subsection{Compression Test on FETUBE}

The compression behavior of the FETUBE was determined by compression test and the modulus of elasticity in compression was calculated by the following equation $\sigma_{\mathrm{c}}=$ $[(\mathrm{Fc} / \mathrm{A}) /(\Delta \mathrm{L} / \mathrm{d})]$. The conditioned specimen was placed on the base plate of the UTM perpendicularly. The geometry of the sample is tabulated in Table.6. The compressive force on the FETUBE sample was applied by a flat heads as shown in Figure. 6. During the test, the cross-head was moved down at $25 \mathrm{~cm} / \mathrm{s}$ speed deforming the sample until failure of the sample and the modulus of elasticity in compression was calculated using above equation. 


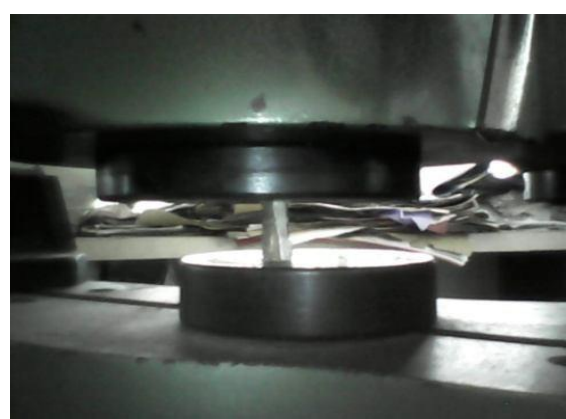

Figure. 6 Compression test on FETUBE

Table.9 Compression Testing results of FETUBE

\begin{tabular}{|c|c|c|c|c|c|c|c|}
\hline $\begin{array}{c}\text { Sample } \\
\text { description }\end{array}$ & $\begin{array}{c}\text { Diameter of } \\
\text { sample }\end{array}$ & $\begin{array}{c}\text { Sam ple } \\
\text { Length } \\
(\mathbf{m m})\end{array}$ & $\begin{array}{c}\text { Area } \\
\left(\mathbf{m m}^{\mathbf{2}}\right)\end{array}$ & $\begin{array}{c}\text { Compression } \\
\text { force } \mathbf{F c}(\mathbf{K N})\end{array}$ & $\begin{array}{c}\text { Compression Force } \\
\mathbf{F c}(\mathbf{N})\end{array}$ & $\begin{array}{c}\text { Change in length } \\
\text { of sample (mm) }\end{array}$ & $\begin{array}{c}\text { Compressive Strength } \\
\left(\mathbf{N} / \mathbf{m m}^{\mathbf{2}}\right)\end{array}$ \\
\hline \multirow{3}{*}{$\begin{array}{c}12 \mathrm{~mm} \\
\text { FETUBE }\end{array}$} & 11.9 & 25 & 111.16 & 2.88 & 2880 & 20.12 & 63.18 \\
\cline { 2 - 8 } & 12.01 & 25 & 113.23 & 2.51 & 2510 & 19.23 & 46.14 \\
\cline { 2 - 8 } & 12 & 25 & 113.04 & 2.12 & 2120 & 19.33 & 39.69 \\
\hline \multirow{2}{*}{$8 \mathrm{~mm}$} & 8.02 & 25 & 50.49 & 1.5 & 1500 & 19.41 & 42.62 \\
\cline { 2 - 8 } FETUBE & 8.07 & 25 & 51.12 & 1.49 & 1490 & 18.75 & 37.63 \\
\cline { 2 - 8 } & 7.95 & 25 & 49.61 & 1.29 & 1290 & 15.65 & 22.11 \\
\hline \multirow{2}{*}{$6 \mathrm{~mm}$} & 5.97 & 25 & 27.98 & 0.75 & 750 & 14.78 & 15.66 \\
\cline { 2 - 8 } FETUBE & 6.04 & 25 & 28.64 & 0.71 & 710 & 14.52 & 14.29 \\
\cline { 2 - 8 } & 6.01 & 25 & 28.35 & 0.62 & 620 & 13.88 & 11.82 \\
\hline
\end{tabular}

\subsection{Tensile strength Test on FETUBE.}

Tensile strength tests were performed by fixing the test specimens in between the parallel clamps on top and bottom side of the UTM. The geometry of the test specimen is tabulated in Table.6. The test specimen's axis is placed perpendicular to the axis of the clamps. Force was applied to the sample by the force transducer to the moveable cross- head. The cross-head speed was maintained at $25 \mathrm{~cm} / \mathrm{s}$ and loading was applied till the failure of the test specimen. A digital data acquisition system showed the variations in the force acting on the test specimen and the deformation at which FETUBE failed was recorded. The mechanical properties of test specimen like modulus of elasticity, toughness and tensile strength were calculated.

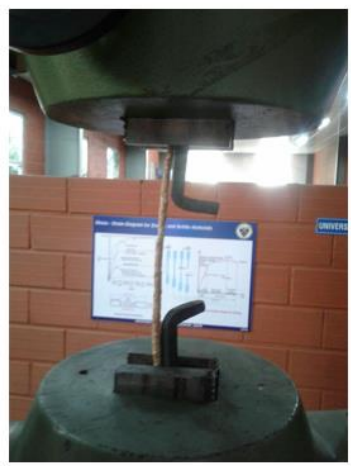

(a)

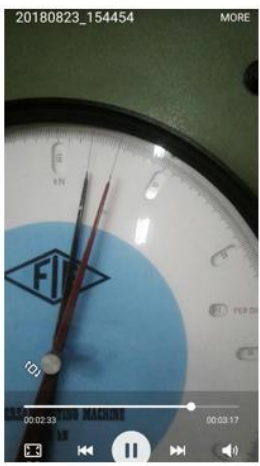

(b)

Figure. 7 Tensile Test on FETUBE 
Table.10 Tensile Testing results of FETUBE

\begin{tabular}{|c|c|c|c|c|c|c|c|}
\hline $\begin{array}{c}\text { Sample } \\
\text { description }\end{array}$ & $\begin{array}{l}\text { Diameter } \\
\text { of sample }\end{array}$ & $\begin{array}{c}\text { Sam ple } \\
\text { Length } \\
(\mathrm{mm})\end{array}$ & $\begin{array}{l}\text { Area } \\
\left(\mathrm{mm}^{2}\right)\end{array}$ & $\begin{array}{c}\text { Tensile } \\
\text { force } \\
\operatorname{Fc}(K N)\end{array}$ & $\begin{array}{c}\text { Tensile } \\
\text { Force } \\
\text { Fc(N) }\end{array}$ & \begin{tabular}{|c|} 
Change in \\
length of \\
sample \\
(mm) \\
\end{tabular} & $\begin{array}{l}\text { TensileStrength } \\
\qquad\left(\mathbf{N} / \mathbf{m m}^{\mathbf{2}}\right)\end{array}$ \\
\hline \multirow{3}{*}{$\begin{array}{l}12 \mathrm{~mm} \\
\text { FETUBE }\end{array}$} & 11.9 & 300 & 111.16 & 2.01 & 2010 & 304.2 & 51.23 \\
\hline & 12.01 & 300 & 113.23 & 2.03 & 2030 & 305.11 & 42.14 \\
\hline & 12 & 300 & 113.04 & 2.11 & 2110 & 303.2 & 70.00 \\
\hline \multirow{3}{*}{$\begin{array}{c}8 \mathrm{~mm} \\
\text { FETUBE }\end{array}$} & 8.02 & 300 & 50.49 & 1.3 & 1300 & 308.1 & 25.49 \\
\hline & 8.07 & 300 & 51.12 & 1.35 & 1350 & 309.7 & 21.97 \\
\hline & 7.95 & 300 & 49.61 & 1.17 & 1170 & 310.3 & 18.20 \\
\hline \multirow{3}{*}{$\begin{array}{c}\text { 6mm } \\
\text { FETUBE }\end{array}$} & 5.97 & 300 & 27.98 & 0.81 & 810 & 314.1 & 12.26 \\
\hline & 6.04 & 300 & 28.64 & 0.71 & 710 & 312.01 & 12.47 \\
\hline & 6.01 & 300 & 28.35 & 0.74 & 740 & 315.3 & 10.25 \\
\hline
\end{tabular}

\subsection{Bending Test on FETUBE}

Bending behavior is very important property of the tube and the maximum bending moment was calculated by equation $\sigma_{b}=M_{y} / I$ and $M=F_{b} x$ L(refer Table.5). The geometry of the test sample is tabulated in Table.6. The bending property of the FETUBE was determined by simply supported teat and the test specimen axis is placed perpendicular to the plunger axis. Both end of the FETUBE specimen was fixed rigidly to the fixture with the help of a screw clamp with two inner semi-circular rims. The vertical force was applied by the chisel heads at the middle of the mounted specimen at a distance of $90 \mathrm{~mm}$ from the fixed point as shown in Figure. 8. Test was conducted till the failure of the test specimen.

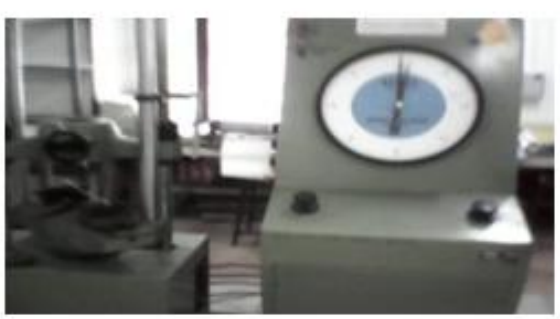

(a)

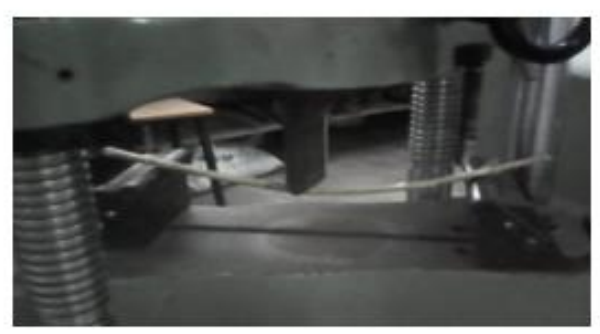

(b)

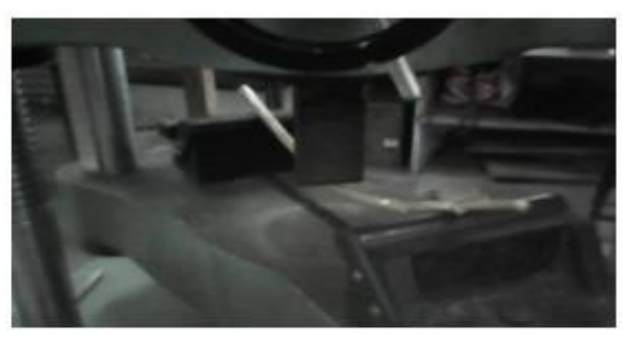

(c)

Figure. 8 Bending Test on FETUBE

Table.11 Bending Testing results of FETUBE

\begin{tabular}{|c|c|c|}
\hline $\begin{array}{c}\text { Sample } \\
\text { description }\end{array}$ & $\begin{array}{c}\text { Diameter } \\
\text { of sample }\end{array}$ & $\begin{array}{l}\text { Compression } \\
\text { force Fc (N) }\end{array}$ \\
\hline \multirow{2}{*}{$\begin{array}{c}12 \mathrm{~mm} \\
\text { FETUBE }\end{array}$} & 11.9 & 2021 \\
\cline { 2 - 3 } & 12.01 & 1997 \\
\cline { 2 - 3 } & 12 & 1943 \\
\hline \multirow{2}{*}{$\begin{array}{c}\text { 8mm } \\
\text { FETUBE }\end{array}$} & 8.02 & 1140 \\
\cline { 2 - 3 } & 8.07 & 1087 \\
\cline { 2 - 3 } & 7.95 & 1051 \\
\hline \multirow{3}{*}{$\begin{array}{c}6 m m \\
\text { FETUBE }\end{array}$} & 5.97 & 981 \\
\cline { 2 - 3 } & 6.04 & 583 \\
\cline { 2 - 3 } & 6.01 & 554 \\
\hline
\end{tabular}




\subsection{Impact Test on FETUBE}

The impact teat on FETUBE was performed for determining the energy required to shear the sample in transverse as well as along the axis. The impact test can be done in two types but Charpy impact test was performed on FETUBE. The test specimen required for Charpy impact test should be of length $55 \mathrm{~mm}$ and was placed in horizontal against the loading RAM. Load is to be released from $135^{\circ}$ by using "V" notch for shearing as shown in the figure. 9.

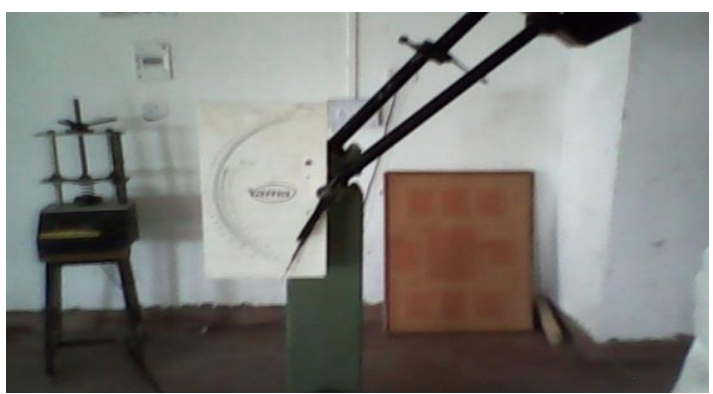

Figure. 9 Impact Test on FETUBE

Table.12 Impact Testing results of FETUBE

\begin{tabular}{|c|c|c|}
\hline $\begin{array}{c}\text { Sample } \\
\text { description }\end{array}$ & $\begin{array}{c}\text { Diameter } \\
\text { of sample }\end{array}$ & $\begin{array}{c}\text { Energy in } \\
\text { Joule }\end{array}$ \\
\hline \multirow{2}{*}{$\begin{array}{c}12 \mathrm{~mm} \\
\text { FETUBE }\end{array}$} & 11.9 & 473 \\
\cline { 2 - 3 } & 12.01 & 447 \\
\cline { 2 - 3 } & 12 & 433 \\
\hline \multirow{2}{*}{$\begin{array}{c}\text { FETU } \\
\text { FETUE }\end{array}$} & 8.02 & 290 \\
\cline { 2 - 3 } & 8.07 & 270 \\
\cline { 2 - 3 } 6mm & 7.95 & 267 \\
\cline { 2 - 3 } FETUBE & 5.97 & 107 \\
\cline { 2 - 3 } & 6.04 & 97 \\
\hline
\end{tabular}

\subsection{Torsion Test on FETUBE}

The Torsion test on FETUBE was executed to determining the torque required to shear the test specimen. Test specimen required for torsion teat should be of length $350 \mathrm{~mm}$ and it should be clamp horizontally in the jaws provided on the testing machine as shown in figure. 10.

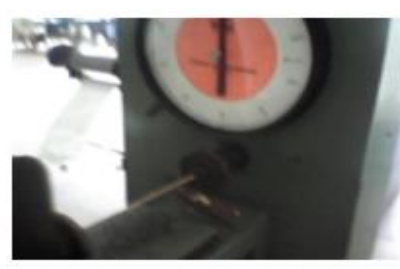

(a)

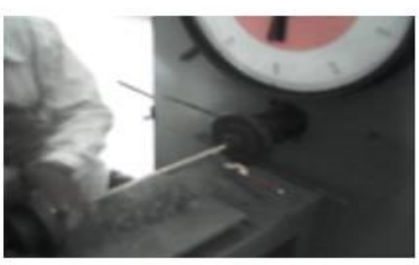

(b)

Figure.10 Torsion Testing on FETUBE

Table.13 Torsion Testing results of FETUBE

\begin{tabular}{|c|c|c|}
\hline $\begin{array}{c}\text { Sample } \\
\text { des criptio } \\
\mathbf{n}\end{array}$ & $\begin{array}{c}\text { Diameter } \\
\text { of sample }\end{array}$ & $\begin{array}{c}\text { Energy in } \\
\text { Joule }\end{array}$ \\
\hline \multirow{2}{*}{$\begin{array}{c}12 \mathrm{~mm} \\
\text { FETUBE }\end{array}$} & 11.9 & 98.75 \\
\cline { 2 - 3 } & 12.01 & 94.5 \\
\hline \multirow{2}{*}{$8 \mathrm{~mm}$} & 12 & 92.4 \\
\cline { 2 - 3 } FETUBE & 8.02 & 43.3 \\
\cline { 2 - 3 } & 7.95 & 39.29 \\
\hline \multirow{2}{*}{$6 \mathrm{~mm}$} & 5.97 & 23.25 \\
\cline { 2 - 3 } FETUBE & 6.04 & 21.45 \\
\cline { 2 - 3 } & 6.01 & 19.875 \\
\hline
\end{tabular}




\subsection{Moisture Content in FETUBE}

FETUBE test specimens were oven dried at $105^{\circ} \mathrm{C}$ for $24 \mathrm{~h}$ by using electrical oven as shown in the below figure.11. The test specimens were weighted before and after drying and the moisture content was determined by using the equation,

\section{Moisture Content $=(\mathrm{SB}-\mathrm{SA}) / \mathrm{SB} \times 100$}

Where:

- $\quad S B=$ Sample mass before drying

- $\quad \mathrm{SA}=$ Sample mass after drying

\section{- $\quad$ FETUBE with cross sectional dia $12 \mathrm{~mm}$}

Sample mass before drying $=21.56 \mathrm{~g}$

Sample mass after drying $\quad=18.11 \mathrm{~g}$

Moisture content $=(21.56-18.11) / 21.56 \times 100$

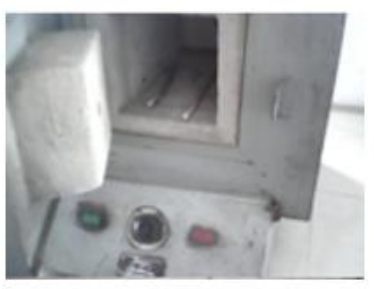

(a)

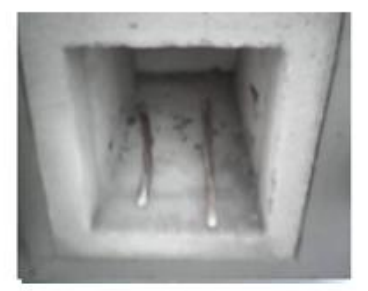

(b)

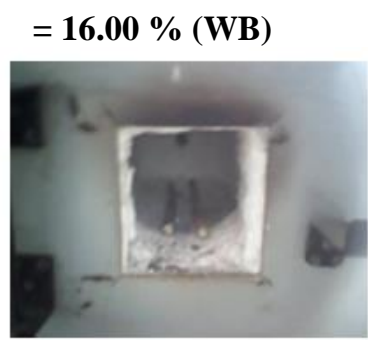

(c)

Figure. 11 Electric Oven setup and Moisture Test for FETUBE

- $\quad$ FETUBE with cross-sectional dia $8 \mathrm{~mm}$

Sample mass before drying $=16.59 \mathrm{~g}$

Sample mass after drying $\quad=14.23 \mathrm{~g}$

Moisture content $\quad=(16.59-14.23) / 16.59 \times 100$

$$
=14.22 \%(\mathrm{WB})
$$

\section{- $\quad$ FETUBE with cross-sectional dia 6 mm}

Sample mass before drying $=13.25 \mathrm{~g}$

Sample mass after drying $=11.98 \mathrm{~g}$

Moisture content $=(13.25-11.98) / 13.25 \times 100$

$$
=9.58 \%(\mathrm{WB})
$$

\section{CONCLUSION}

Poultry feather fiber based filled circular tube also known as FETUBE was tested to determine and review physical and mechanical properties. FETUBE is available in running lengths up to $1.25 \mathrm{~m}$. The FETUBE diameter ranges from $4 \mathrm{~mm}$ to $12 \mathrm{~mm}$ with or without quill reinforcement. FETUBE will have quill reinforcement at the center and quill reinforcement is available only with FETUBE of diameter greater than $8 \mathrm{~mm}$. Various tests were performed on FETUBE like Compression Test, Tensile Test, Shear Test (Single and Double Shear), Torsion Test, Impact test and Moisture content tests. Similar tests were conducted on conditioned Maize stalk of approximate diameter 12 to $17 \mathrm{~mm}$. Test results of FETUBE was compared with the test results of Maize stalk and tabulated in Table.14. 
Table. 14 Test result summary

\begin{tabular}{|c|c|c|}
\hline & $\begin{array}{l}\text { Maize } \\
\text { Stalk }\end{array}$ & $\begin{array}{l}\text { FETUBE } \\
(12 \mathrm{~mm})\end{array}$ \\
\hline $\begin{array}{c}\text { Double } \\
\text { Shear strength }\left(\mathrm{N} / \mathrm{mm}^{2}\right)\end{array}$ & 28.52 & 50.72 \\
\hline $\begin{array}{c}\text { Single } \\
\text { Shear strength }\left(\mathrm{N} / \mathrm{mm}^{2}\right)\end{array}$ & 29.77 & 51.28 \\
\hline $\begin{array}{c}\text { Compres sive } \\
\text { strength } \\
\left(\mathrm{N} / \mathrm{mm}^{2}\right) \\
\end{array}$ & 7.54 & 63.18 \\
\hline $\begin{array}{c}\text { Tensile strength } \\
\left(\mathrm{N} / \mathrm{mm}^{2}\right)\end{array}$ & 40.2 & 51.23 \\
\hline $\begin{array}{l}\text { Bending Compression force Fc } \\
(\mathrm{N})\end{array}$ & 1620 & 2021 \\
\hline $\begin{array}{l}\text { Impact Energy } \\
\text { (Joule ) }\end{array}$ & 656.46 & 473 \\
\hline Torque in N.m & 108.75 & 98.75 \\
\hline Moisture content & $18.00 \%$ & $16 \%$ \\
\hline
\end{tabular}

Detailed review of the test results shows that the superior property of the feather fiber based filled circular tube against the agriculture based byproduct namely maize stalk. Maize stalks are used in industrial products like "Corn Board", a maize stalk based composite panels and other civil building materials. Thus it is evident from the test results that feather fiber based tube can be used as reinforcements in composite panels and also in generic commercial applications. It is also advantageous to use feather fiber based tubes in composites as reinforcement, due to the fact that feathers and father based tubes have fire retarding characteristics and resistance to bacterial or fungal growth.

\section{REFERENCE}

[1] https://www.statista.com/statistics/826711/india-poultry-meatconsumption/

[2] USDA, "Poultry-Production and Value 2008 Summary," in United States Department of Agriculture, National Agricultural Statistics Service (2009). Available online: http:// usda.mannlib.cornell.edu/usda/nass/PoulProdVa/2000s/2009/Poul ProdVa-05-29-2009.pdf

[3] A.A. Onifade, N.A. Al-Sane, A.A. Al-Musallam, and S. AlZarban, Bioresour. Technol., 66, 1 (1998).

[4] C.K. Hong and R.P. Wool, J. Appl. Polym. Sci., 95, 1524 (2005).

[5] A.M. Lucas and P.R. Stettenheim, Avian Anatomy: Integument, United States Agricultural Research Service, Washington (1972).

[6] A.M. Woodin, Biochem. J., 57, 99 (1954).

[7] C.E. Graham, H.K. Waitkoff, and S.W. Hier, J. Biol. Chem., 177, 529 (1949).

[8] W.F. Schmidt, "Innovative Feather Utilization Strategies," in Poultry Waste Management Conference, Springdale, Arkansas (1998).

[9] D.S. Franer, Avian Biology, Academic Press, New York (1982). Introduction to Poultry feather fiber

[10] Martinez-Hernandez, Ana L.; Velasco-Santos, Carlos; De Icaza, Miguel; Castano, Victor M.(2005); Microstructural characterisation of keratin fibres from chicken feathers; International Journal of Environment and Pollution; 23(2), p 162178

[11] W.F. Schmidt,"(1998) Innovative Feather Utilization Strategies", national Poultry waste Management Symposium Proceedings,

[12] PN-EN ISO 5270: (2011): Fibrous pulps- Laboratory sheets Estimation of physical properties

[13] P. P. Purslow AND J. F. V. Vincent (1978); Mechanical properties of primary feathers from the Pigeon; exp. Biol., 73, 251-260
[14] Chen C, Chuanbao C, Xilan M, Yin T, Hesun Z(2006). Preparation of non-woven mats from all-aqueous silk fibroin solution with an electrospinning method. Polymer. 47(18): 6322-7

[15] Wdowiak T.(1970) Technology to produce non-woven by a papermaking method (In Polish). Przegląd Papierniczy 94

[16] Reddy, Narendra and Yang, Yiqi, "Structure and Properties of Chicken Feather Barbs as Natural Protein Fibers" (2007). Faculty Publications - Textiles, Merchandising and Fashion Design.

[17] https://digitalcommons.unl.edu/textiles_facpub/26

[18] https://www.reference.com/science/much-feather-weighfeb66e65ee2cf966

[19] https://cluckin.net/a-chickens-feathers.html 